\title{
THE POWER OF MODERN TECHNOLOGIES IN THE FICTION OF DON DELILLO
}

This paper analyses the literary work of an American writer Don DeLillo, who belongs among contemporary American writers. He focuses on the manner in which contemporary human consciousness has been shaped being influenced by consumer and military technologies, media and daily life of information. Modern consumer technologies have a strong impact on men. In DeLillo's fictions, modern technologies are not just simple objects in everyday life of his characters. They are able to shape the consciousness of each human. Telephones, nuclear bombs, computers, television sets and modern appliances present a psychological phenomenon which provides the possibilities for actions, what more, it influences the perception of each human being. In his literary work, Don DeLillo discovers the interaction between human characters and their technological environment. DeLillo's characters find expression through the material forms of the technologies they fetishize, but these material forms simultaneously capture and limit the nature of the kind of transcendence they are able to offer. Technology appears to DeLillo's characters as a kind of human dream, which in turn, influences the kind of dreams and desires they have, and thus also the ones they realize in a technological form. They exist in an interaction between technology and self-definition or self-deception. The diversity of modes that is illustrated in DeLillo's fictions is supplemented by the technologically mediated confluence of his characters and the field of cultural objects in which they appear.

Keywords: modern technology, fiction, Don DeLillo, media, information

\section{Introduction}

Don DeLillo's is one of the most significant writers of the modern American era. His position among the most influential American millennial authors is as secure, as such an ontologically dubious status can be. On the long list of DeLillo's works, one might find many bestsellers and creations with a huge cultural impact. Harold Bloom [1], the literary critic, has included DeLillo in his list of four major contemporary American novelists and "named him as one of the four major American novelists of his time, along with Thomas Pynchon, Philip Roth, and Cormac McCarthy” [2, p. 88] DeLillo covered a huge variety of topics in his writings. He worked with ideas about the complexity of language, but he also worked with ideas about the television, nuclear war, sports, performance art, mathematics, the advent of the digital age and economics, and even wrote about the Cold War and global terrorism. His unique literary work highlights the concept of an individual in modern society being impacted by the advantages of Science and new technologies. His "early fictions employ cinematic allusions and techniques to reveal the harmful effects of cinematic representation of subjectivity.
The early stories preview both the concerns of his later fiction and the frightening late twentieth-century world that those works depict” [3, p. 3]. On the long list of DeLillo's works, one might find many bestsellers and creations with a huge cultural impact. DeLillo covered a huge variety of topics in his writings. He worked with ideas about the complexity of language, but he also worked with ideas about the television, nuclear war, sports, performance art, mathematics, the advent of the digital age and economics, and even wrote about the Cold War and global terrorism. In DeLillo "the relationship between individuals and their technological environment is characterized by technopsychic interphoricity, a mutual carrying across of attributes and ontological values between psychology and electro-mechanism" [4, p. 6]. Randy Laist selected four books he considered the most important regarding the topic of the technological impact on the postmodern society. His first choice was Americana because it was the first major book written by DeLillo, the second choice was White Noise, as it is the best renowned of his books, the third one was Underworld, as it is a huge literary creation, and the last one was Cosmopolis. Throughout the years, DeLillo kept on, as all human beings do, evolving and changing. Laist's collection of

\footnotetext{
* Martina Pavlikova

Department of Journalism, Constantine the Philosopher University in Nitra, Slovakia

E-mail: mpavlikova@ukf.sk
} 
chosen books gives us an insight to the growth of a genius mind, since the first chosen book, Americana, was printed out in 1971, while Cosmopolis came out in the year 2003.

\section{Modern technologies and media}

All of the four books chosen for inspection are remarkable works of a single author, yet remain different and special in their own ways, given their unique characters. The factor that was the most important in Americana is that it establishes the theme that would eventually become all-pervasive in all his future works. It is a reality, in which every American citizen would sooner or later find themselves - the reality of one's identity enfolded in an American media transmission, since the people influence the media and define the media's identity [5], but this mechanism works both ways [4, p. 15].

White Noise targets television specifically. It describes the American Environment that was able to pollute itself and effectively disseminate its own pollution to the whole society via television broadcast. The participants of the novel are all experiencing this new, surprisingly overwhelming influence of the television. Even more so, this circumstance is pronounced in the Underworld. The 1997 novel paints the culture-scape so accurately, that it becomes a commonplace, a home, a completely new reality, in fact. The real human feelings and aspirations have not completely diminished, but they have mutated and changed significantly [4, p. 15].

The artistry of DeLillo spikes in his novel. Cosmopolis represents author's self-conscious isolation created by the intertwining worlds of reality and the virtual reality. The main protagonist of Cosmopolis is a 28years old man, a billionaire, a picture of American success, a techno-fetishist, an American per se. This young man pursues his dream of self-rarefaction into the final virtual pension of life and death, achieving the most convincing experience of technologically-mediated subjectivity DeLillo was ever able to impart upon his readers, showing that techno-fetishism is a disturbing trend that renders us all senseless and aggressive [4, p. 15].

The impact of the technological advance is one of the biggest issues DeLillo occupies himself with. In a way, it is accurate to say that Laist walks on a path of self-discovery with all of DeLillo's characters. He embarks on journeys, studies the movements and sympathizes with all the protagonist, as a quiet narrator, as a sharp spectator, as all the heroes themselves. His attachment to DeLillo's heroes enables him to inspect DeLillo's work from various angles, and still remain objective in his analysis. It is more than obvious, that the "typical DeLillian character is suspended between dread and awe, between randomness and conspiracy, between science and religion. But all of these outbreaks are symptoms of the fundamental, viral interfusion of self and circuitry” [4, p. 4].
Don DeLillo's novel Americana is full of criticism of technologically-induced conditions placed on human lives. One of the characters, David the photographer, the man behind the camera, is trying to prove his own existence, in a way. $\mathrm{He}$ is creating an art piece that describes the artist, the art itself, but also helps David discover the depth of his own profession. As he is creating his movie, shooting the pictures and slowly putting together the realization of his ideas, he becomes the first significant witness of the techno-fetishistic changes in DeLillo's creations. David, "so fond of mirrors in the fourdimensional world, imagines the potency of the camera as a kind of two-dimensional mirror, a mirror that frees its subject from the exigencies of space and time. This two-dimensionality offers a kind of middle-ground between human life and nonexistence" [4, p. 47]. He struggles with control over his ideas with the untold, yet undiscovered influence. The power of the camera is both the subject of David's film and his motivation as the filmmaker, since the cinematic itself is at the same time both the vector of the aspiration and the aspiration itself. David is constantly widening the readers' impression that the technologically-mediated structures express the dire desire to annul all self-consciousness whatsoever, supporting the idea that the modern persons - persons of the year 1971 or so - would eventually have to end up strung in an existential insecurity. DeLillo's fiction operates with the predicament, in which the future, the post-apocalyptic, is already here and present $[6$, p. 5]. Somehow, the world and all those who live in it, have found themselves in an ongoing situation, which has already changed who they are. It is not a process they slowly succumb to; it is a sudden realization of the state of things. Americana presented us with a character whose identity is inseparably connected to technologies and the mass media [7]. Marshall McLuhan "suggested the structure of metaphor as a persuasive model for conceptualizing the continuity between the conventionally discontinuous terms of human subject and technological object” [4, p. 5].

\section{Hyperspace and simulacrum of reality}

The evolution of DeLillo's thinking unfolds in 1985. White Noise is an unprecedented work of fiction by DeLillo's genius and combines the description of culture, philosophy and the transcendental directive of technological influence. The protagonists of White Noise are intellectuals. They think on a higher level than the regular American citizens, they see and contemplate ideas higher than average. A good example of this are Jack Gladney, the professor of Hitler studies, and his counterpart Murray Siskind, the professor of Elvis Presley studies. These characters do somehow hint their natures to a bright reader since they are somewhat defined by their names in the traditional nomen omen fashion used by many authors. DeLillo depicts Murray as a person who is able to incorporate anything, 
no matter how prosaic, into his theoretical-mystical purviews, seeking and successfully finding transcendental significance in the earthliest of things. Naturally, "television, as the arbiter of all stereotypicality, holds a privileged place in his perception. Murray reads television the way a seer reads entrails, with critical attentiveness and steadfast faith" [4, p. 69]. He finds a referential bridge between a supermarket and the world of television. This uncanny resemblance creates a parity of hyperspace; he sees the supermarket as a three-dimensional projection of the code-world.

On the other hand, Jack sees the supermarket as a threat, as another weapon which could be used to inflict harm upon one's existence, another way to exploit a person's vulnerability. This presents readers with a strong friction, which, in turn, brings an extremely vivid example of the ambivalent in human thinking.

White Noise works with two sides of a coin. It describes the world, puts it in a spotlight, trying to find its way out of the technologically-induced confusion, and yet it also realistically dismisses itself with cold rationality, with self-defense and with the benefit of the doubt. For DeLillo, there is no description more accurate than the conflict of two friends, two counter-parts who antagonize in their pursuit of finding the truth, only to realize how lost they actually are in a world that does not feel any compassion towards them. In White Noise, a new narrator is likewise mystified, he is existentially bound to the technological environment [4, p. 109].

Underworld presents us with a huge, complicated and everconnected world listening to the media and news. It brings deeper and wider understanding of one's position under the technological superpower. It's the externalization of previously private spheres of human life. Advertisement of underwear, the professional establishments focused on adultery, the massmarketing of condoms - this all characterizes the psychic life of Underworld's heroes [4, p. 111].

DeLillo still offers his protagonists, and by extensions his readers, a way to self-validate. His Underworld characters do, after a struggle, finally achieve a degree of freedom, but they do not do it by escaping or resisting technological claims on selfhood according to the classic romantic paradigm, but quite oppositely, they find a way to incorporate the mood of techno-cultural immersion into their own strategies of self-understanding. Rather than becoming externalized into the impersonal significations of material culture, DeLillo's heroes adapt the psycho-technological systems of paranoid ecology to their own creative purposes [4, p. 139]. This novel is the first DeLillo's post-9/11 novel. In the previous works, DeLillo has often included the World Trade Center, and by the time Cosmopolis was completed, the World Trade Center had already been destroyed. DeLillo was able to see its impact, to incorporate the mechanism he noticed after the attack and include his new-found testimony of technological age into Cosmpolis [4, p. 154]. Eric, the main protagonist of Cosmopolis, is, in Laist's words, arguably the most involved with the surrounding technoscape. Eric is a person of unspeakable wealth, which allows him to get in contact with all the new technology, which in the end defines him. DeLillo offers an explanation about the current state of things, putting the image in Eric and his everyday life into his novel. The technology is absorbing humanity, the humane is melting into it, slowly diminishing and by overusing these tools, humanity becomes fuel for the pieces of technology that leave nothing behind, and in the end, cease to exist themselves [4, p. 157].

Throughout the second half of Cosmopolis, Eric thrives on the threat of death. His own existence is something he so consciously clings to [4, p. 172].

In one of the most recent works of DeLillo, we see a continuity of the thought-provoking removal of what is humane in order to become something more. ZERO $K$, DeLillo's recent novel that came out in 2016, takes us one step closer to the loss of things most humane - death among them. The novel discusses one of the most troubling things a human mind can ever face. The possibility to cheat death. Could it be possible? Should it be done?

After all, we are born without a choice, without the ability to refuse this sudden happening; we are given life. What makes us so sure we should also die in this manner?

DeLillo continues in clarifying and confusing his protagonists, and again, readers. No matter how much attention one pays to DeLillo's books, we never seem to know what exactly DeLillo believes. He portraits characters, heroes, people so believable, that they become alive in our heads, so we completely focus on their fates, while DeLillo remains only the authoring person - the one who shows the reality, but does not force his beliefs upon anybody.

The main protagonists of the book, Jeff, Ross and Artis, deal with this question in their own way, putting the weakened dying body in a stasis, in order to preserve it and revive it later, when technology advances to the point of curing even what means a certain death now.

\section{Conclusion}

The question that DeLillo is constantly spinning and turning in his effort to see all the angles is a rather simple one: How much of the humane can be lost, before the human itself becomes a casualty? He offers a compelling argument, potently showing one's need to contemplate their own existence, and yet somehow still losing it in everyday life surrounded by technological advancement, which, sadly, slowly takes away everything authentic and humane about a human himself [8].

The culmination of DeLillo's realizations over the years is interestingly changing, giving us the chance to watch and follow the evolution in his thinking, but, far more importantly, we can follow ourselves - the human society that undergoes the same changes on a much bigger scale. DeLillo is an author with the ability to see the slightest glimpse in our society, but also with the ability to accurately record it and, via his extraordinary books, 


\section{KOMNIKCCle}

impart this knowledge on the rest of the society. Even though the answer still seems to elude him, somehow DeLillo never seems to lose his hope for humanity. What he always leaves open are the doors of salvation. Everyone has the possibility to save themselves, to find and preserve their identity. Humanity is not threatened by the technological advancement, after all [9]. What lingers as a shadowy malice above all of us is the ignorance of each other, and even more so the ignorance of ourselves. Humans suffer this fate because they all so often forget about being humans in the first place. "It [technology] is an escape from our personal mortality. Catastrophe. It overwhelms what is weak and fearful in our bodies and minds" [10, p. 66].

\section{References}

[1] BLOOM, H.: Bloom's Modern Critical Views: Don DeLillo. Chelsea House, Philadelphia, 2003.

[2] ESTES, A. K.: Cormac McCarthy and the Writing of American Spaces. Rodopi, New York, 2014.

[3] OSTEEN, M.: American Magic and Dread: Don DeLillo's Dialogue with Culture. University of Pennsylvania Press, Philadelphia, 2000.

[4] LAIST, R.: Technology and Postmodern Subjectivity in Don DeLillo's Novels. Peter Lang Publishing, Inc., New York, 2010.

[5] LESKOVA, A., VALCO, M.: Identity of Adolescents and its Dimensions in the Relation to Mass Media: Philosophical-Ethical Reflections. XLinguae, 10(3), 324-332, 2017; ZAHOREC, J., HASKOVA, A., MUNK, M.: Results of a Research Evaluating Quality of Computer Science Education. Informatics in Education, 11(2), 283-300, 2012.

[6] BOXALL, P.: Don DeLillo: The Possibility of Fiction. Routledge, New York, 2006.

[7] See also articles about technocratic society, mass-media technology, and science: GOGORA, A.: The Text Mining of Ethics and Information Technology. Communications - Scientific Letters of the University of Zilina, 18(3), 3-8, 2016; KRALIK, R., TINLEY, J. S.: Kierkegaard's Ethics as an Answer to Human Alienation in Technocratic Society. Communications - Scientific Letters of the University of Zilina, 19(1), 25-29, 2017; VALCO, M., BOEHME, A. J.: Christian Faith and Science Can Science Enhance Theology? European Journal of Science and Theology, 13(3), 89-97, 2017.

[8] AMBROZY, M., KRALIK, R., MARTIN, J. G.: Determinism vs. Freedom: Some Ethics-Social Implications. XLinguae, 10(4), 48-57, 2017; TAVILLA, I., KRALIK, R., MARTIN, J. G.: A Brief Recollection of Kierkegaard's Testimony on Reformation 500th Anniversary. XLinguae, 11(1), 354-362, 2018; MAHRIK, T.: Kierkegaardian Pointers to Metaethics. European Journal of Science and Theology, 13(5), 119-130, 2017; ZALEC, B.: On Not Knowing Who We Are: The Ethical Importance of Transcendent Anthropology. Synthesis Philosophica, 26(1), 105-115, 2011.

[9] SLIVKA, D.: Intentional Abuse of Social Networks with the Goal of Promoting Ideas of Antisemitism, Racism, and Xenophobia. Communications - Scientific Letters of the University of Zilina, 19(1), 54-58, 2017; KONDRLA, P., REPAR, P.: Ontological Consequences of the Ethics of Technology. Communications - Scientific Letters of the University of Zilina, 19(1), 19-24, 2017.

[10] DeLILLO, D.: Zero K. Scribner, New York, 2016. 